\title{
Puebla: uma voz profética em favor da celebração e da vida
}

\author{
Puebla: \\ a prophetic voice in favor of celebration and life
}

\section{Resumo}

Aproveitando a oportunidade da comemoração dos quarenta anos da publicação do Documento de Puebla, nossa exposição quer ser um contributo para matizar a importância que esse Documento deu à teologia litúrgicosacramental. O alvo preciso de nossa apresentação é a investigação do parágrafo 917 do Documento de Puebla. Nesse parágrafo se verifica uma densa e profunda síntese do projeto amoroso de Deus, que, manifestando-se na história da salvação, deseja abraçar e alcançar todos os seres humanos e, através deles, a inteira criação. Essa descida de Deus em busca de suas criaturas é o impulso dinamizador que provoca nos seres humanos um imperativo responsorial. Unidos a toda a criação, eles, por se sentirem participantes do dom da salvação, tornam-se capazes de se dirigir a Deus numa liturgia de louvor e ação de graças.

Palavras-chave: Trindade. Puebla. Concílio Vaticano II. Liturgia. Evangelização.

\section{Abstract}

With a view to commemorating the forty years of the publication of the Puebla Document, our article wants to be a contribution to clarify the 
importance that this Document gave to liturgical-sacramental theology. The purpose of our presentation is the investigation of paragraph 917 of the Puebla Document. Thus there is a dense and profound synthesis of God's loving project, which he, himself, manifests in the history of salvation and wishes to embrace and reach all human beings and through them the entire creation. This descent of God in search of his creatures is the impelling impulse that stimulates in humanity a responsorial imperative. Together with all creation, because they are an integral part of the gift of salvation, they become capable of addressing God in a liturgy of praise and thanksgiving.

Keywords: Trinity. Puebla. Vatican Council II. Liturgy. Evangelization.

\section{Introdução}

Neste ano de 2019 estamos celebrando os 40 anos da publicação do Documento de Puebla. Trata-se do documento conclusivo da III Conferência Geral do episcopado latino-americano, que se realizou na cidade de Puebla de los Angeles, no México, nos dias 28 de janeiro a 13 de fevereiro de 1979. "A evangelização no presente e no futuro da América Latina" foi o tema que norteou tudo aquilo que foi abordado no Documento de Puebla.

A III Conferência Geral do Episcopado Latino-Americano havia sido convocada pelo Papa Paulo VI para acontecer no mês de outubro de $1978 .{ }^{1}$ Todavia, por conta do seu falecimento, em 6 de agosto de 1978, ela foi adiada. Coube ao recém-eleito papa João Paulo II inaugurar a conferência de Puebla, o que aconteceu por ocasião de sua primeira viagem apostólica ao México. Em seu discurso inaugural, o papa sugeriu aos bispos que as conclusões de Medellín (1968) e as propostas contidas na Exortação Apostólica Evangelii Nuntiandi de Paulo VI (1975) servissem como ponto de partida para os trabalhos a serem desenvolvidos no Documento de Puebla.

João Paulo II, na solene sessão de abertura da III conferência geral do episcopado latino-americano, em 28 de janeiro de 1979, reconhece ser ela "uma hora histórica para a Igreja na América Latina". Em virtude disso, como que num tom epiclético, invoca sobre o continente latino-americano e seus

\footnotetext{
${ }^{1}$ Paulo VI convocou oficialmente a III Conferência Geral do episcopado latino-americano no dia 12 de dezembro de 1977, sob o tema: "Evangelização no presente e no futuro da América Latina”. O pontífice assinalou que ela seria celebrada de 12 a 18 de outubro de 1978.
} 
bispos reunidos no Espírito Santo, no desejo de que seja ele a inspirar as propostas daquela Conferência:

É também uma hora de graça, esta, assinalada pela passagem do Senhor, por uma particularíssima presença e ação do Espírito de Deus. Por isso invocamos este Espírito, com confiança, ao princípio dos trabalhos. E por isto também, quero agora suplicar-vos, como um irmão a irmãos muito queridos: durante todos estes dias da Conferência e em cada um dos seus atos, deixai-vos conduzir pelo Espírito, abri-vos à sua inspiração e ao seu impulso; que seja Ele e nenhum outro espírito o que vos guie e conforte. Sob este Espírito, pela terceira vez nestes últimos vinte e cinco anos, vós, Bispos de todos os Países e representando o Episcopado de todo o Continente latino-americano, congregais-vos para juntos aprofundardes o sentido da vossa missão perante as novas exigências dos vossos povos. ${ }^{2}$

Uma boa parte do conteúdo e das propostas de Puebla foram levados adiante pela IV Conferência, latino-americana de Santo Domingo (1992), ocasião em que também celebramos os 500 anos da evangelização do nosso continente. Numa linha de um progresso teológico-pastoral da Igreja latino-americana, podemos dizer que o material produzido em Puebla não deixa também de ter sua continuidade e atualidade na quinta Conferência do Episcopado Latino-americano, cujo fruto foi o Documento de Aparecida (2007). Esse mesmo reflexo, em sua atualidade e seu dinamismo, não cessa de iluminar e inspirar a reflexão teológica e a práxis pastoral da nossa Igreja e de nossas comunidades. Considerando tudo isso, é com dever de justiça e, ao mesmo tempo, com grande satisfação, que nos propomos a oferecer uma colaboração no sentido de realçar o atual e perene valor do texto de Puebla, em particular, motivados pelo seu quadragésimo aniversário de promulgação.

O alvo preciso de nossa apresentação é a investigação teológicolitúrgica do parágrafo 917 do Documento de Puebla. Ele, como uma gema preciosa, se encontra incrustado na moldura dos dois parágrafos que lhe estão entorno e que lhe conferem sentido. Esses três parágrafos, por sua vez, estão contextualizados, de forma ampla, na III parte do Documento, a qual se destina abordar a evangelização na Igreja da América Latina sob a perspectiva da comunhão e participação. Nessa III parte, em seu terceiro capítulo - intitulado "Liturgia, oração particular, piedade popular" -, encontramos, finamente, o

${ }^{2}$ JOÃO PAULO II, PP., Discurso do papa João Paulo II na solene sessão de abertura da III conferência geral do episcopado latino-americano. 
contexto próximo onde está fincado o parágrafo da nossa abordagem. Com essa contextualização desejamos realçar o valor e a importância que o tema da liturgia teve nas reflexões e no texto final da III Conferência Geral do episcopado latino-americano. É como se o povo de Deus do nosso continente, representado de modo exímio por seus pastores, movido pelo Espírito Santo, bradasse, de forma nova, depois de quase vinte anos, aquele grito que brotou da Igreja conciliar: "A liturgia é o cume para o qual tende toda a ação da Igreja e, ao mesmo tempo, a fonte de que promana sua força". ${ }^{3}$

\section{Por uma "autêntica teologia litúrgica"}

A investigação teológico-litúrgica do parágrafo 917 do Documento de Puebla somente poderá ser devidamente feita se tivermos como pressuposto o tema da teologia litúrgica. A esse respeito, devemos registrar a enfática declaração do nosso Documento quando quis mostrar a importância e a urgência de uma renovação da liturgia na Igreja latino-americana: "É necessário que toda esta renovação seja orientada por uma autêntica teologia litúrgica". ${ }^{4}$ É como se o Documento de Puebla dissesse, em outros termos, que a tão custosa e suada renovação conquistada pelo Concílio Vaticano II somente poderia ser implantada, experimentada e vivenciada em profundidade no continente latino-americano graças a um sério e incansável projeto de formação cristã, onde uma "autêntica teologia litúrgica" tivesse o seu lugar de primazia. Diante dessa urgência teológica e pastoral, cabe-nos neste nosso item uma breve investigação do que significa essa expressão usada em nosso Documento. ${ }^{5}$

Cremos que ninguém melhor do que S. Marsili ${ }^{6}$ para nos introduzir no tema da teologia litúrgica, uma vez que ele é, reconhecidamente, uma

\footnotetext{
${ }^{3} \mathrm{SC} 10$.

${ }^{4}$ DP 918. "Sem sombra de dúvida, a causa de muitas crises na prática litúrgica pós-conciliar foi a ausência de uma séria iniciação no sentido de (natureza da liturgia, isto é, nos princípios, critérios e normas litúrgicas postulados pelo Concilio": PALUDO, F., Vida litúrgica no Seminário, p. 21.

${ }^{5}$ Segundo Puebla, a liturgia deve ser "baseada numa autêntica teologia e purificada dos vícios do passado": SILVA, J. A., A celebração do mistério de Cristo ao longo da história, p. 513.

${ }^{6}$ Salvatore Marsili (1910-1983) foi um exímio mestre de liturgia. Foi co-fundador e primeiro diretor do Pontifício Instituto Litúrgico de Roma e durante muitos anos exerceu a função de diretor da Rivista Liturgica, tendo sido também presidente da Associação de Professores de Liturgia da Itália. Conviveu por algum tempo com o liturgista alemão Odo Casel e, como ele, se convenceu da importância de se abordar a liturgia a partir da teologia bíblica do "mystérion". Foi ainda um dos mentores da coleção litúrgica "Anámnesis".
} 
das maiores competências nesse âmbito. O nosso autor é conhecido como "teólogo da liturgia", uma vez que sua pesquisa, desenvolvida ao longo de muitos anos, consistiu, essencialmente, em radicar e fundamentar um discurso teológico a partir da "teologia do mistério de Cristo". Essa sua intuição brota de um profundo conhecimento da história da liturgia, bem como das fontes da Sagrada Escritura e dos Padres da Igreja. Ele tinha um foco preciso de pesquisa: demonstrar de que modo a liturgia da Igreja é capaz de tornar atual e vivo o mistério da salvação realizado por Cristo. ${ }^{7}$

Segundo S. Marsili, a celebração litúrgica é, por excelência, o locus onde a história da salvação continua o seu trajeto de revelação até a consumação dos tempos, segundo o sábio desígnio arquitetado por Deus. É da celebração do mistério pascal que a própria Igreja nasce, é construída e se desenvolve; ela é também o ponto de partida de toda reflexão-discurso sobre Deus, mais precisamente, da teologia. Nesse sentido, declara o próprio teólogo: "Pressuposto fundamental, para mim é a dimensão sacramental da revelação, dimensão que emerge em cada momento da história da salvação e que não pode ser abandonada justamente no momento em que, com a "teologia", queremos chegar à compreensão profunda desse fato ou dessa realidade". ${ }^{8}$

S. Marsili defendia a tese de que a liturgia pode e deve de ser considerada - juntamente com a Sagrada Escritura - como o fundamento de uma autêntica teologia. Partindo do pressuposto de que a teologia consiste no discursar sobre Deus a partir do conhecimento de Deus e da sua Palavra, e que esta mesma Palavra se apresenta na história da salvação em dois momentos distintos e complementares - anúncio e realização-atuação do mistério de Cristo -, ele crê que a teologia deveria ser explicada a partir da experiência desses dois momentos, assumidos historicamente pelo Verbo eterno. Nesse sentido, teríamos uma teologia apresentada em dois momentos integrados entre si, representados respectivamente pela Sagrada Escritura (teologia bíblica) e pela celebração da liturgia (teologia litúrgica).

A teologia bíblica, estudando a história da salvação em fase de revelação, isto é, no primeiro momento histórico assumido pela Palavra-Deus, que é

\footnotetext{
${ }^{7}$ Acerca da intuição teológica de S. Marsili (JAVIER FLORES, J., Introdução à teologia litúrgica, p. 241-261).

${ }^{8}$ MARSILI, S., Sinais do mistério de Cristo, p. 12. Acerca da dimensão sacramental da revelação e da economia da salvação: BUYST, I., Sacramentalidade da liturgia na Sacrosanctum Concilium (SC), Constituição sobre a sagrada liturgia, p. 93-94.
} 
o do anúncio e da sua realização em Cristo, no operar da Palavra descobre a lei da sacramentalidade, que é fundamental para o exato conhecimento da revelação. Esta, de fato, aparece não como proposição de verdade abstratamente quiditativa (quid sit Deus), mas como realidade salvífica divina que está presente e ativa na humanidade de Cristo e por causa da humanidade de Cristo (cur Deus homo), que não só se torna símbolosacramento de salvação, mas que revela como a salvação, ou melhor, toda a relação de Deus com o homem só pode realizar-se por via do simbolismo sacramental. Se a teologia bíblica nos mostra no sacramento-Cristo a sacramentalidade como lei básica da revelação (salvação em ato), a teologia litúrgica será a que, na celebração, nos há de mostrar a contínua realização da mesma revelação naquela situação de sacramentalidade derivada, que é constituída pelos sacramentos da igreja, que são a comunicação/ participação pelo sacramento-Cristo. ${ }^{9}$

É nesse íntimo diálogo e nessa fecunda relação entre a teologia bíblica e a teologia litúrgica que consiste, precisamente, a originalidade do pensamento teológico de S. Marsili. Sua teologia se constrói e se desenvolve a partir do manancial da celebração litúrgica. Com isso, o nosso autor procura resgatar o sentido que a liturgia tinha na antiguidade cristã, sobretudo no pensamento teológico do Oriente. Ela era tida como "theologia prima", uma vez que representa o primeiro momento da profissão de fé da Igreja. Transformada em "liturgia vivida", ela era ainda a primeira forma de linguagem concreta, que, com a sua gramática ritual-simbólica, servia de ponto de partida para a reflexão sobre o dado da fé professada e as ulteriores reflexões teológicas e definições dogmáticas ("theologia secunda"). ${ }^{10}$

Por essa razão, M. Alberta, profundo conhecedor da teologia marsiliana, nos lembra que S. Marsili preferiu sempre falar de "teologia da liturgia" ou "teologia litúrgica" e nunca de teologia e liturgia, como se a liturgia estivesse numa posição subordinada ou paralela à teologia. "Ele subtraiu a liturgia da visão dogmático-especulativa, pois nesta estrutura aquela é considerada não in actu, isto é, como presença salvífica de Cristo na qual a reflexão teológica tem seu ponto de partida, mas só como locus theologicus, ou seja, como uma fonte histórica a ser usada na qualidade de testemunho para provar um dogma de fé ou uma formulação elaborada teoricamente". ${ }^{11}$

\footnotetext{
${ }^{9}$ MARSILI, S., Teologia Litúrgica, p. 1183-1185.

${ }^{10}$ MARSILI, S., Teologia Litúrgica, p. 1178.

${ }^{11}$ ALBERTA, M., Apud MARSILI, S., Sinais do mistério de Cristo, p. 14.
} 
À luz da concepção marsiliana, temos uma teologia litúrgica quando o falar sobre Deus se origina e se fundamenta naquilo que ele denomina de "sacramentalidade" da revelação. Nesse sentido, a revelação não é somente a manifestação de uma verdade comunicada por Deus ou sobre Deus. É, sobretudo, uma entrega que Deus faz de si mesmo em vista da salvação do homem, ou, em outros termos, para que o homem participe da vida de Deus. Por isso, necessariamente, essa revelação somente pode alcançar o homem pela via da sacramentalidade, a começar pelo símbolo-sacramento de Deus por excelência na sua humanidade: Cristo.

Teologia litúrgica, pois, segundo S. Marsili, é:

A teologia que adota como seu o discurso sobre Deus, partindo da revelação vista na sua natureza de fenômeno sacramental, para o qual convergem o acontecimento de salvação e o rito litúrgico que o reapresenta. Desse modo, a teologia litúrgica é, necessariamente e antes de mais nada, teologia da economia divina, isto é, da presença e da ação de Deus no mundo, do Deus que no mundo quer realizar-se como salvação eterna com dimensão antropológica. Isso aconteceu como sinal profético no AT e como sinal real acontece no NT, primeiro em Cristo, sacramento humano de Deus na encarnação, depois nos homens, a quem Cristo se comunica por meio de sacramentos separados e distintos, ele que é sacramento total de salvação. ${ }^{12}$

É um dado comprovado o mérito que cabe a S. Marsili no sentido de propor uma teologia que brota da fonte da liturgia, que ele mesmo denominou de "teologia litúrgica". "Essa teologia litúrgica é a teologia da presença e da ação de Deus na história da salvação humana [...]. É a presença de Cristo na encarnação, na humanidade, nos seres humanos. Não é, portanto, uma teologia de verdades abstratas [...]. É a teologia viva de um fato, de um acontecimento, algo que é real, que existe, que se chama Cristo, que se chama Igreja [... ${ }^{13}$

A teologia litúrgica é, por conseguinte, a "primeira", necessária e indispensável para que o discurso sobre Deus, discurso, "cristão", isto é, recebido como experiência sacramental de Cristo. Nesse sentido, a teologia litúrgica não exclui teologia alguma que seja reflexão humana sobre Deus, mas nunca pode ser por ela substituída. A teologia litúrgica é a única que é naturalmente consoante e totalmente adequada a uma

\footnotetext{
${ }^{12}$ MARSILI, S., Teologia Litúrgica, p. 1184.

${ }^{13}$ MARSILI, S., Sinais do mistério de Cristo, p. 15.
} 
espiritualidade cristã no significado pleno e do termo. É, pois, à teologia que deve chegar e à qual deve conduzir toda a catequese, bem como todas as atividades pastorais". ${ }^{14}$

A liturgia, entendida como "teologia litúrgica, é a experiência cristã do mistério do culto celebrada como momento histórico da salvação". Em outros termos, conforme enfatizado por S. Marsili, é a celebração da liturgia como "último momento da história da salvação". ${ }^{15}$ Essa perspectiva do nosso autor foi genialmente resgata pela teologia do Concílio Vaticano II, de modo particular na constituição litúrgica Sacrossanctum Concilium. Nos parágrafos de 5 a 7 dessa constituição, dedicados à natureza da liturgia, notamos a explícita intenção do Concílio de tratar da revelação em chave histórico-salvífica, conforme um método já utilizado pela teologia bíblica. No primeiro parágrafo a ênfase recai sobre a obra da salvação que fora prenunciada por Deus e que, finalmente, é realizada pelo mistério pascal de Cristo. Por esse mistério, Cristo, "morrendo, destruiu a nossa morte e, ressuscitando, restaurou-nos a vida"; e, "do lado de Cristo morto na cruz, brotou o admirável mistério da Igreja”. No parágrafo seguinte, o Documento sublinha que a obra realizada por Cristo continua na Igreja e se coroa na liturgia. Com efeito, o anúncio do Cristo pascal feito pelos apóstolos é coroado na celebração litúrgica dos sacramentos (nesse parágrafo são mencionados, explicitamente, os sacramentos da eucaristia e do batismo). Finalmente, o último parágrafo se dedica à presença de Cristo na liturgia: "Para realizar tal obra, Cristo está sempre presente à sua Igreja, especialmente nas ações litúrgicas". ${ }^{16}$

A guinada copernicana feita pelo Concílio Vaticano II em sua abordagem litúrgica foi precisamente o resgate da liturgia a partir da sua natureza, do seu mistério. Ela é, por excelência, o lugar e o momento onde a história da salvação continua progressivamente o seu desdobrar até o eschaton. Nesse sentido,

\footnotetext{
${ }^{14}$ MARSILI, S., Teologia Litúrgica, p. 1184-1185. “A Igreja antiga conhecia praticamente uma única forma de espiritualidade, que se encontra, por exemplo nas catequeses mistagógicas dos Padres da Igreja. Ela tinha uma característica muito importante: a harmonia e o equilíbrio entre vida e de oração e vida ativa" - SÁNCHEZ, V., Por que celebramos?, p. 270.

${ }^{15}$ MARSILI, S., A liturgia, momento histórico da salvação, p. 39-190. Sobre a liturgia como último momento da história da salvação indicamos a seguinte pesquisa: SODI, M., Liturgia, p. $115-152$

${ }^{16}$ SC 5-7. Segundo Puebla, a liturgia deve ser compreendida a partir do mistério pascal. O ponto de partida para essa ótica foi a teologia inaugurada pela Sacrosanctum Concilium: SANTOS FRADE, G., Puebla e a liturgia, p. 78.
} 
ela é uma realidade teológica, tendo, portando, um cunho essencialmente de "teologia litúrgica".

Ao auspiciar que "é necessário que toda esta renovação seja orientada por uma autêntica teologia litúrgica", o Documento de Puebla se enche de esperança no sentido de que os cristãos e cristãs do nosso continente descubram cada vez mais o tesouro escondido no mistério da fé que celebram e do qual são chamados a viver.

\section{A dinâmica trinitária do mistério da liturgia}

Conforme anteriormente assinalado, o alvo da nossa reflexão é a investigação teológico-litúrgica do parágrafo 917 do Documento de Puebla. O item anteriormente abordado - uma autêntica teologia litúrgica como condição sine qua non para que se dê uma profunda renovação na vida litúrgica da Igreja latino-americana - quis ser o trampolim que nos impulsionasse para o nosso escopo: "o Pai, por Cristo e no Espírito, santifica a Igreja e, por ela, o mundo; mundo e Igreja por sua vez, por Cristo e no Espírito, dão glória ao Pai". Estamos persuadidos de que esse parágrafo seja não somente uma penetrante, vivaz e arguta declaração do documento de Puebla, como também uma genial e densa síntese da revelação escriturística e do pensamento da tradição eclesial e litúrgica da fé cristã do primeiro milênio. Essa asserção do documento transpira o núcleo da profissão de fé da própria Igreja. Portanto, isso equivale a dizer que essa proposição teológico-pastoral do documento parte de um dado litúrgico, fruto da experiência da ecclesia orans.

Consideremos neste nosso item o timbre trinitário do parágrafo 917 do Documento de Puebla, visceralmente marcado por uma dinâmica interna (ad intra) e externa (ad extra). Tal dinâmica poderia ser muito bem sintetizada como a fórmula "do Pai ao Pai", que, necessariamente, supõe uma mediação cristológica e um dinamismo pneumatológico, ${ }^{17}$ essa mediação e esse dinamismo abraçam e assumem a Igreja e o mundo em todas as suas realidades. Nesse sentido, nada, absolutamente nada, fica fora do circuito amoroso e vivificante que parte de Deus e a ele retorna: "Como a chuva e a neve descem do céu e para lá não voltam sem terem regado a terra [...], tal ocorre com a Palavra que sai da minha boca: ela não torna a mim sem fruto;

\footnotetext{
17 “A dimensão pneumática é a única perspectiva capaz de derrubar as barreiras sociais, étnicas, culturais e religiosas. E Puebla enfatiza isso ao retornar "às fontes bíblicas e à centralidade do Evangelho": NEF ULLOA, B. A., Espiritualidade latino-americana a partir de Puebla, p. 114.
} 
antes, ela cumpre a minha vontade e assegura o êxito da missão para a qual a enviei” (Is 55,10-11). Nesse dinamismo gerador de vida, devemos matizar que Deus tem a absoluta primazia, tanto na comunicação que faz de si mesmo ad extra como no acolhimento último da resposta que vem do mundo através de seu povo. ${ }^{18}$

É necessário aqui recordar aquilo que foi verificado no item anterior da nossa proposta: a novidade da concepção litúrgica do Concílio Vaticano II é exatamente a sua teologia histórico-salvífica, de tal modo que é a partir dessa mens eclesial que se pode hoje falar em "teologia litúrgica". Com efeito, a obra da salvação idealizada por Deus realizou-se cabalmente pelo mistério pascal de Cristo e, virtude da potência do Espírito Santo; desse engenhoso desígnio "brotou o admirável mistério da Igreja". ${ }^{19}$

"O Pai "entrega" seu Verbo e seu Sopro, e tudo é chamado à existência. Tudo é dom dele, manifestação de sua glória: nada é sagrado ou profano, tudo é pura efusão de sua santidade. Nosso Deus não faz isso ou aquilo, como a causa primeira do deus dos filósofos: dá-se em tudo o que existe, ama e isso é bom; dá-se e isso é belo". ${ }^{20}$ É a entrega de Deus, uma kénose movida unicamente por amor e total gratuidade, e com um único desejo: que todos e tudo participem da alegria do Pai: "Trazei o novilho cevado e matai-o; comamos e festejemos, pois este meu filho estava morto e tornou a viver; estava perdido e foi reencontrado". E começaram a festejar" (Lc 15,24)

M. Kunzler, com singular sagacidade, capta e expressa teologicamente a kénose radical de Deus no ato da revelação que faz de si mesmo; tal esvaziamento divino tem a capacidade de provocar em cada criatura humana uma oferta existencial, uma resposta livre e plena a essa revelação. Para esse teólogo - que opta por abordar a revelação de Deus a partir de uma teologia bíblico-litúrgica ${ }^{21}$ - a criatura humana não pode "criar" e "inventar" Deus. Segundo as leis da revelação bíblica, Deus, na manifestação e entrega que faz de si mesmo em forma de "catábase", somente por uma resposta livre pode ser acolhido e aceito. Dessa forma é na gratuidade do dom da revelação e na liberdade de um consentimento a ela que se pode tomar parte na comunhão de Deus. Do contrário, nos lembra o nosso teólogo, qualquer forma de

\footnotetext{
${ }^{18}$ A liturgia é, essencialmente, comunicação entre Deus e o ser humano: ROSAS, G., O que celebramos?, p. 91-93.

${ }^{19} \mathrm{SC} 5$.

${ }^{20}$ CORBON, J., A fonte da liturgia, p. 21.

${ }^{21}$ KUNZLER, M., La liturgia della Chiesa, p. 35-246.
} 
"discurso sobre Deus" correria o risco de se tornar mera projeção humana e, até mesmo, ser o princípio de uma patologia mental. Acolhendo a catábase divina, aceitamos e celebramos o fato de Deus agir a todo instante e através de todos os acontecimentos, sempre em vista da nossa salvação. Acolher a catábase revelatória de Deus é estarmos dispostos a responder a ela, o que significa, portanto, descobrirmo-nos capazes de "anábase". Somente, então se estabelece o equilíbrio "catabático-anabático". E é a partir desse equilíbrio que se pode compreender a natureza da liturgia como diálogo entre Deus e o homem, e não simplesmente como um culto a ser prestado a um Deus onipotene e "autobastante", conforme está tão impresso em nosso instinto religioso. Não. O Deus que se revela na historia salutis quis se fazer "história" para poder contar com suas criaturas como partner de uma aventura, uma "dança de amor". Dessa forma, a descida de Deus ao homem (dimensão catabática ou soterilógica) torna possível a ascensão humana no louvor, na invocação, na celebração do amor (dimensão anabática ou latrêutica). ${ }^{22}$

A teologia litúrgica, por sua natureza, é também antropológica. Salvaguardando a primazia da ação divina originária, ela mostra que a glória de Deus, no seu movimento catabático, de forma alguma eclipsa ou perde de vista o homem. Na verdade, a glória de Deus é que o homem viva, isto é, seja salvo, conforme tão bem nos lembra Santo Irineu. ${ }^{23} \mathrm{E}$ é por isso que Deus se revela ao homem. No entanto, essa salvação somente pode ser levada a termo se contar com a "responsabilidade" (como capacidade de responder) humana. A primazia catabática é incompatível com a compreensão unilateral da liturgia (redução anabática, antropocêntrica). A relação de Deus com os homens e as mulheres, portanto, é sempre dialógica. Passar de uma concepção litúrgica meramente cultual e estática para uma outra doxológico-responsorial e dinâmica foi a genial conquista da teologia litúrgica do Concílio Vaticano II. À luz da Sacrosanctum Concilium, falar em natureza da liturgia é pensar em um Deus que se revela e no ser humano que tornou-se capaz de lhe dar um consentimento livre.

Deus, "quer que todos os homens sejam salvos e alcancem o conhecimento da verdade" (1Tm 2,4). "Falou outrora falado aos pais pelos profetas de muitas maneiras" (Hb 1,1). Quando veio a plenitude dos tempos, enviou seu Filho [...]". ${ }^{24}$ Como que repassando toda a antiga economia num flash, a teologia litúrgica concilar pousa o seu olhar na "plenitude dos tempos", kairós em que

${ }^{22}$ KUNZLER, M., La liturgia della Chiesa, p. 38-39.

${ }^{23}$ SANTO IRINEU, Apud CORBON, J., A fonte da liturgia, p. 124.

${ }^{24} \mathrm{SC} 5$. 
Deus, finalmente, condensa sua pedagogia catabática com a catábase, agora, do seu amado Filho. Segundo Paulo, ele é o "mistério escondido desde os séculos e desde as gerações" (Cl 1,26), mas, agora, manifestado. "De hoje para o futuro, tudo o que é carne está impregnado da energia do amor. Quando o rio da vida se uniu à energia do acolhimento, tomou um nome, o nome finalmente humano, no qual o Pai se diz e nos diz seu Filho muito amado: "Jesus". Então, a alegria explode!". ${ }^{25}$ E a etapa mais eloquente da catábase do Verbo feito carne foi precisamente o evento da sua páscoa e do seu mistério pascal (que compreende, também, em seu arco de mistério salvífico, Pentecostes e a manifestação da Igreja).

O mistério pascal de Jesus Cristo, isto é, a passagem de sua morte à sua ressurreição, triunfando diante da morte e do pecado, mediante a glorificação do Espírito Santo, é o núcleo do mistério oculto durante séculos no seio do Pai e agora revelado na história. E esse é também o centro do mistério litúrgico, que é o centro da história sagrada da salvação ou realização da obra da redenção. Nesse sentido, percebe-se a relação essencial entre o mistério pascal e a liturgia e, de modo definitivo, entre o mistério pascal e o mistério da Igreja. ${ }^{26}$

A anábase do Ressuscitado ao Pai, a sua Ascensão, torna-se, se assim podemos dizer, uma epíclese viva: "Eis que eu vos enviarei o que meu Espírito. Por isso permanecei na cidade até serdes revestidos da força do alto" (Lc 24,49). Com o evento de Pentecostes, dá-se, então, a catábase do Espírito de Deus. Com ela, manifesta-se o mistério da Igreja e toda a criação é renovada. É um acontecimento inédito. Os "últimos tempos" da economia salvífica são inaugurados. "As irrupções do Espírito Santo durante os "tempos" que precederam este dia são incontáveis [...]. Mas o que advém neste dia é mais do que uma intervenção do Espírito sobrevindo após tantas outras: é um começo". ${ }^{27}$ Conforme nos recorda tão bem o Catecismo da Igreja Católica, é no evento de Pentecostes, sopro vivificador e recriador, que a Igreja se manifesta ao mundo na qualidade de Corpo de Cristo. "O dom do Espírito inaugura um tempo novo na "dispensação do mistério": o tempo da Igreja, durante o qual Cristo manifesta, torna presente e comunica a sua obra de salvação pela

${ }^{25}$ CORBON, J., A fonte da liturgia, p. 27.

${ }^{26}$ MALDONADO, L.; FERNANDÉZ, P., A celebração litúrgica, p. 248.

${ }^{27}$ CORBON, J., A fonte da liturgia, p. 51. 
liturgia da sua Igreja, "“até que Ele venha' (1Cor 11,26)". ${ }^{28}$ Nesse mesmo parágrafo, reforça ainda mais o Catecismo: "Cristo vive e age, agora na sua Igreja e com ela, de um modo novo, próprio deste tempo novo. Age pelos sacramentos e é a isso que a Tradição comum do Oriente e do Ocidente chama "economia sacramental". ${ }^{29}$

Tendo enfatizado até agora a catábase de cada uma das pessoas divinas, todas elas envolvidas no "trabalho" (leitourgía) de realização do projeto salvífico, é premente sublinhar a dimensão anabática, responsorial que foi confiada à liberdade de cada criatura. Nunca é demais sublinhar que, conforme nos mostra M. Kunzler, Deus, tomando a iniciativa de salvar o homem e o mundo, torna-se o leitourgós, o servidor por excelência de suas criaturas, sempre entregue a um trabalho que jamais se interrompe (Jo 5,17). ${ }^{30}$

Impulsionados pelo Espírito Santo, o homem e a mulher descobrem também sua vocação de "liturgos". "Exorto-vos [...] a que ofereçais vossos corpos como hóstia viva, santa e agradável a Deus: este é o vosso culto espiritual" (Rm 12,1). Vozes que sobem a Deus na única "voz" - a da Palavra feita carne. Vozes, expressão de existências agradecidas pelo dom da vida. Vozes dos que não têm voz nem vez na história. Vozes de toda a criação, que ainda "geme e sofre as dores de parto" ( $\mathrm{Rm} 8,22)$. "O povo clama pela salvação e pela comunhão que o Pai lhe preparou e, no meio de suas lutas por viver e encontrar o sentido profundo da vida, espera de nós, bispos, o anúncio da Boa-Nova". ${ }^{31}$

"Eu vi, eu vi a miséria do meu povo que está no Egito. Ouvi o seu clamor por causa dos seus opressores, pois eu conheço as suas angústias. Por isso eu desci a fim de libertá-lo das mãos dos egípcios, e para fazê-lo subir daquela terra [...]” (Ex 3,8-9). É o clamor do povo de Deus que, em forma de anábase, sobe ao Senhor e provoca a sua contínua catábase junto aos seus. Isso fica bastante evidenciado na segunda parte do parágrafo 917 do Documento de Puebla: “O Pai [...]; mundo e Igreja por sua vez, por Cristo e no Espírito, dão glória

${ }^{28}$ CEC 1076.

${ }^{29}$ A respeito da presença de Cristo que age em sua Igreja, por meio dos sacramentos, conferir: CASTELLANO, J., Liturgia e vida espiritual, p. 129-187.

${ }^{30}$ Leitourgía, literalmente "ação do povo e/ou "ação para o povo". O termo é aqui aplicado a Deus enquanto age e opera em favor de todos. Nesse sentido, estamos priorizando a dimensão catabática de todas as ações de culto a Deus. Por outro lado, a liturgia é também ação de todo o povo de Deus, sobretudo no culto que lhe é prestado. Conferir a esse respeito: KUNZLER, M., La liturgia della Chiesa, p. 54.

${ }^{31}$ DP 340. 
ao Pai". Claramente vê-se aqui um movimento ascensional e responsorial: a Igreja se une ao mundo para clamar e, ao mesmo tempo, glorificar a Deus no anseio e na expectativa da "revelação dos filhos de Deus" $(\mathrm{Rm} 8,19)$. Nesse sentido, não seria impreciso falar em uma verdadeira vocação doxológica de cada criatura humana e de toda a criação suscitada pelo Espírito do Senhor. "O desejo e a obra do Espírito no coração da Igreja é que nós vivamos da vida de Cristo ressuscitado. Quando ele encontra em nós a resposta da fé que suscitou, realiza-se uma verdadeira cooperação. ${ }^{32}$

Cooperação (sinergia) - e aqui poderíamos falar em equilíbrio catabáticoanabático: uma realidade que tão bem caracteriza a fé cristã no culto prestado a Deus. Esse culto tem uma dimensão constitutivamente teândrica: por um lado é trinitário (teocêntrico, cristológico e pneumático), por outro lado é eclesialantropológico-cósmico. Esta dimensão trinitária do culto cristão deve ser vista e entendida sob o seu aspecto econômico, isto é, segundo a dinâmica histórica da salvação, que tem como fundamento a própria trinitariedade testemunhada pelo Novo Testamento. ${ }^{33}$

A celebração cristã ganha o seu selo de autenticidade exatamente porque é toda convergente "ao" Pai, "por" Cristo, "no" Espírito Santo. Na dýnamis do Espírito, a Igreja se associa ao louvor prestado a Deus, travando com ele uma experiência de vida e comunhão. Assim, a liturgia, em sua ontologia, diria até mesmo, em sua "ontogenética", outra coisa não é senão a celebração-atuação do desígnio de Deus realizado por Cristo, "no" e "por" obra do Espírito Santo.

O movimento trinitário da economia, celebrado e professado pela liturgia, parte de Deus e percorre, então, o seu fluxo dinâmico: "do Pai, pelo Filho, no Espírito, ao Pai" - "O Pai, por Cristo e no Espírito, santifica a Igreja e, por ela, o mundo [...]”. Essa manancialidade trinitária - que estrutura e dinamiza os textos eucológicos usados na liturgia - é suficiente para demonstrar o quanto a práxis cúltica da Igreja, desde as suas origens,

\footnotetext{
${ }^{32}$ CEC 1091.

${ }^{33}$ Essa dimensão trinitária do culto cristão deve ser vista e entendida sob o seu aspecto econômico, isto é, segundo a dinâmica histórica da salvação, que tem como fundamento a própria trinitariedade testemunhada pelo Novo Testamento. Nesse sentido, destacamos como paradigma a perícope de Ef 1,3-14: Deus Pai, por meio de seu Filho e sob a ação de seu Espírito, nos elegeu como seus filhos adotivos e nos selou com o Espírito da promessa, que é o penhor de nossa herança. Destacamos aqui o teor constitutivamente econômico na realização desse plano de salvação, segundo a teologia trinitário-econômica de Paulo. Igual atenção merecem os trechos de Ef 2,4-8.19-22; Cl 1,15-20; Fl 2,6-11. A partir das fontes bíblicas, afirmamos ser a liturgia uma ação trinitária: ESCOBAR, F., A celebração do mistério de Cristo, p. 30-35.
} 
quis expressar a sua consciência de fé na profissão trinitária de Deus. Em particular, destacamos a tradição litúrgica do Oriente cristão que, ao longo dos séculos, conservando a qualquer preço a herança legada pelos apóstolos e pelos Padres da Igreja, revelou o cunho trinitário das ações litúrgicas, em especial da eucaristia. Essa diligência do Oriente contribuiu para que a teologia latina procurasse superar um risco que nem sempre pôde ser evitado: "Aquele de considerar a ação litúrgica quase como uma ação binitária (louvor ao Pai prestado pelo Cristo sumo sacerdote), ou trinitária apenas parcialmente (o Espírito visto como efeito da ação litúrgica ou apenas como Pessoa que simul adoratur et conglorificatur)". ${ }^{34}$ Com efeito, a liturgia é "gloria ao Pai, pelo Filho, no Espírito Santo", síntese cúltica que exprime o núcleo do plano soteriológico de Deus: memória da obra redentora realizada pelo Cristo e atualizada na Igreja pelo dom do Espírito Santo. ${ }^{35}$

O fim último do culto prestado a Deus - que é também aquele da revelação bíblica - é fazer com que cada pessoa participe da vida de Deus e seja salva. Tendo sido levada a termo a antiga lei mosaica, na nova economia, é por meio de Jesus Cristo que nos vêm a "graça e verdade", e é "de sua plenitude que todos nós recebemos a graça por graça" (Jo 1,16-17). Gerada e manifestada pela cháris de Deus, que é o próprio Espírito, a Igreja se autocompreende como o Corpo vivificante de Cristo tecido na história humana. Consciente de sua fragilidade, ela é, nessa última etapa da economia salvífica em que estamos vivendo, o locus e o instrumento da salvação e experiência de Deus para todos os homens mediante o "sacramento" do culto divino.

"Por Cristo, com Cristo, em Cristo, a vós, Deus pai todo poderoso, na unidade do Espírito, toda honra e toda a glória, agora e para sempre". É esse o clímax de cada anáfora eucarística, anábase litúrgica por excelência daqueles tomam parte no "sacramento dos sacramentos". Nesse momento, a Igreja se une ao cosmos e a toda criação para glorificar o seu criador e redentor. "A Eucaristia une o céu e a terra, abraça e penetra toda a criação. O mundo, saído das mãos de Deus, volta a Ele em feliz e plena adoração: no Pão Eucarístico, a

\footnotetext{
${ }^{34}$ LAMBIASI, F., Lo Spirito Santo, p. 30.

${ }^{35}$ Longe de ser uma mera metafísica especulativa, o mistério da Trindade foi vivido, desde a mais remota experiência da Igreja, como um acontecimento celebrativo que fora capaz de plasmar a profissão de fé da Igreja e de cada fiel, o que se pode constatar já no querigma apostólico e nas comunidades cristãs da primeira hora. Atualizando essa herança bíblica, o Concílio Vaticano II, ao abordar o tema da liturgia no seu fulcro celebrativo, o contextualiza no plano histórico-salvífico da revelação, sobrelevando, dessa forma, a sua dimensão trinitárioeconômica.
} 
criação propende para a divinização, para as santas núpcias, para a unificação com o próprio Criador". ${ }^{36}$

\section{Mistério celebrado e evangelização em Puebla}

A III Conferência Geral do episcopado latino-americano teve como principal programa e proposta de trabalho o tema da evangelização do nosso continente. A I parte do Documento - "A visão pastoral da realidade latinoamericana" - dedica-se a quatro itens diretamente centrados numa preocupação evangelizadora. No primeiro, é traçada uma linha histórica dos grandes momentos da evangelização na América Latina; em seguida, é apresentada uma visão pastoral do contexto sócio-cultural do nosso continente; em terceiro lugar, nos é apresentado um panorama da realidade pastoral latino-americana hoje; por fim, é proposto um diagnóstico da evangelização no presente e no futuro da América Latina. Com essa parte introdutória, solene abertura de todo o Documento, Puebla faz pensar em um perene eco do querigma que sempre dinamizou a missão apostólica da Igreja. E isso se traduz na própria declaração do Documento: "antes de tudo, queremos identificar-nos: somos pastores da Igreja Católica e Apostólica, que nasceu do coração de Jesus Cristo, o Filho do Deus vivo". ${ }^{37}$

O elã evangelizador de Puebla, portanto, é uma resposta concreta ao mandato do Senhor aos seus discípulos - "Ide, portanto, e fazei que todas as nações se tornem discípulos [...]" (Mt 28,20a) - e se encontra numa esteira de continuidade com a práxis da Igreja apostólica, tão bem interpretada pela teologia do Concílio Vaticano II: "Como foi enviado pelo Pai, também Cristo enviou os apóstolos no Espírito Santo, para pregar o Evangelho a toda criatura [...]. Ao mesmo tempo que anunciavam, realizavam a obra da salvação pelo sacrifício e pelos sacramentos, através da liturgia". ${ }^{38}$ Com feito, essa fabulosa síntese conciliar é o reverberar da mais genuína tradição bíblica e patrística. Nelas, o binômio "evangelização-liturgia" são como que as duas faces da mesma moeda, com uma notificação, no entanto. Uma vez que a liturgia, ainda segundo o do Concílio, é o "cume" e a "fonte" da vida da Igreja, ${ }^{39}$ fica

\footnotetext{
${ }^{36}$ LS 236. A respeito do tema da "eucaristização" do cosmo e de toda a criação: ZIZIOULAS, I., A criação como eucaristia.

${ }^{37} \mathrm{DP} 1$.

${ }^{38} \mathrm{SC} 6$.

${ }^{39} \mathrm{SC} 10$.
} 
fácil intuir que a evangelização deve partir e conduzir à celebração do mistério pascal, núcleo da liturgia. Isso porque "a liturgia não é nossa invenção, pertence à vida da Igreja; é ação de Cristo e, simultaneamente, ação do povo de Deus". ${ }^{40}$

"A tarefa específica da evangelização consiste em anunciar Jesus Cristo", declara Puebla. ${ }^{41}$ Sublinhando a sua linha de continuidade com a tradição eclesial, o nosso Documento reafirma aquilo que o papa Paulo VI - um apaixonado apóstolo da causa do anúncio do Evangelho -, havia declarado poucos anos antes: "Nós queremos acentuar, sobretudo hoje, que nem o respeito e a estima para com essas religiões [religiões não cristãs], nem a complexidade dos problemas levantados são para a Igreja motivo para ela calar, diante dos não-cristãos, o anúncio de Jesus Cristo". ${ }^{42}$ Anunciar Jesus Cristo e o seu Evangelho, princípio e meta da evangelização, tem sido também um dos principais objetivos da incansável missão do papa Francisco. Ao tema da evangelização, ele ainda acrescenta o condimento da alegria, primeiro fruto de quem acolhe a Boa-Nova do Ressuscitado: "A alegria do evangelho enche o coração e a vida inteira daqueles que se encontram com Jesus [...]. Quero, com esta Exortação, dirigir-me aos fiéis cristãos a fim de os convidar para uma nova etapa evangelizadora marcada por esta alegria e indicar caminhos para 0 percurso da igreja nos próximos anos". ${ }^{43}$

Três anos depois dessas palavras proféticas do papa Francisco, a Igreja do Brasil, em suas Diretrizes Gerais da ação evangelizadora, volta a tratar do tema da evangelização com uma forte tônica litúrgica - conforme tão fortemente havia sublinhado Puebla. G. Lutz, ao considerar a proposta pastoral das Diretrizes, manifesta o seu contentamento por ver a Igreja brasileira empenhada em colocar em prática a teologia proposta pelo Concílio Vaticano II e por Puebla (uma práxis pastoral e uma ação evangelizadora que brotam, efetivamente, do mistério da liturgia): "Para o leitor liturgista das novas Diretrizes Gerais da ação evangelizadora da Igreja do Brasil, a afirmação mais importante que fazem sobre a relação da liturgia na ação evangelizadora da Igreja é, sem dúvida aquela citada na Constituição Sacrosanctum Concilium do Vaticano II, que diz: A liturgia 'é o ápice para o qual tende a ação da Igreja e,

\footnotetext{
${ }^{40}$ RAMOS, A., Evangelização e liturgia, p. 423.

${ }^{41}$ DP 407.

${ }^{42}$ EN 53.

${ }^{43}$ EG 1.
} 
ao mesmo tempo, a fonte de onde emana toda a sua força'". ${ }^{44}$ Esse testemunho de G. Lutz - liturgista e pastoralista brasileiro, dedicado por completo em implantar a reforma litúrgica pós-conciliar no Brasil e na América Latina - é de grande relevância para o nosso tema. ${ }^{45}$

Aquilo que J. López Martín fala acerca da liturgia pode, a nosso ver, ser perfeitamente aplicado também à realidade da evangelização: "A compreensão da liturgia é mais completa e coerente quando é situada na perspectiva que lhe é conatural, isto é, dentro da economia salvífica projetada e revelada pelo Pai, realizada pelo Filho e Senhor nosso Jesus Cristo e levada a termo pelo Espírito Santo na etapa da Igreja, que vai desde Pentecostes até o retorno glorioso de Cristo". E, continua o teólogo, o centro da economia salvífica é o "mistério pascal de Jesus Cristo, que, por sua vez, é o núcleo de toda celebração litúrgica. Nesse mistério, realizou-se a salvação que a Igreja anuncia e atualiza na liturgia". ${ }^{46}$ A celebração da salvação pascal operada em favor de todos os homens e mulheres está diretamente vinculada à missão evangelizadora que o Senhor confere à sua Igreja: "Ide e anunciai".

Esta salvação, que Deus realiza e a Igreja jubilosamente anuncia, é para todos, e Deus criou um caminho para Se unir a cada um dos seres humanos de todos os tempos. Escolheu convocá-los como povo, e não como seres isolados. Ninguém se salva sozinho, isto é, nem como indivíduo isolado, nem por suas próprias forças. Deus atrai-nos, no respeito da complexa trama de relações interpessoais que a vida numa comunidade humana supõe. Este povo, que Deus escolheu para Si e convocou, é a Igreja. Jesus não diz aos Apóstolos para formarem um grupo exclusivo, um grupo de elite. Jesus diz: "ide, pois, fazei discípulos de todos os povos" (Mt 28,19). ${ }^{47}$

"A liturgia é o cume para o qual tende toda a ação da Igreja e, ao mesmo tempo, a fonte de que promana sua força": ${ }^{48}$ É a voz que continua, insistentemente, ecoando nos ouvidos da Igreja latino-americana, e que o

${ }^{44}$ LUTZ, G., Uma leitura litúrgica global das Novas Diretrizes, p. 7.

${ }^{45}$ É necessário recordar que a teologia litúrgica de G. Lutz reflete de forma fidedigna o pensamento da Igreja do Brasil no que concerne à renovação, formação e espiritualidade litúrgicas, tão bem expressas pela CNBB: CNBB, Doc. 42, p. 91-99; CNBB, Por um novo impulso à vida litúrgica, 302-327, onde se diz que a espiritualidade litúrgica é bíblica, cristocêntrica, sacramental e encarnada.

${ }^{46}$ LÓPEZ MARTÍN, J., A Liturgia da Igreja, p. 68.

${ }^{47} \mathrm{EG} 113$.

${ }^{48} \mathrm{SC} 10$. 
Documento de Puebla, profeticamente, havia intuído. Na media em que a liturgia for considerada como o fundamento da evangelização, o anúncio do mistério de Cristo - "anunciamos, Senhor a vossa morte e proclamamos a vossa ressurreição", conforme professamos em cada celebração eucarística - poderá ser, livre e conscientemente, acolhido como realização do projeto salvífico do Pai, realizado por Cristo e continuamente atualizado pelo dinamismo do Espírito Santo, sempre em vista da salvação da pessoa humana.

\section{Conclusão}

"Puebla vive"!, declarou há vinte anosa trás J. Comblin: “comecemos constatando um fato: depois de 20 anos, Puebla vive. Nas assembleias, nos encontros, nos debates, nos planejamentos é difícil que não se faça referência a Puebla, e, na maioria das vezes, a um texto em particular. Puebla vive de tal modo na consciência católica que sua lembrança aflora espontaneamente" ${ }^{49} \mathrm{E}$ o que também reafirmamos neste ano em que comemoramos o quadragésimo ano da publicação do Documento de Puebla.

A quinta parte das conclusões de Puebla enfatiza e reconhece que a Igreja latino-americana deseja caminhar sob a ação do Espírito Santo: "o Espírito de Jesus ressuscitado habita na sua Igreja. Ele é o Senhor e doador da vida. É a força de Deus que impele para a plenitude a sua Igreja; é o Amor criador de comunhão de riqueza [...]. Desejamos ser dóceis a essa força e a esse amor". ${ }^{50}$ É a partir dessa potência pneumática que a Igreja do nosso continente deseja pautar o seu celebrar, evangelizar e testemunhar. É nessa dinâmica do sopro de Deus que ela quer apresentar suas opções pastorais, sempre direcionadas ao anúncio de Jesus Cristo e à promoção humana em seus diversos âmbitos.

Os pastores da III Conferência Geral do episcopado latinoamericano afirmam optar por uma "Igreja-sacramento de comunhão", que "numa história marcada por conflitos, oferece energias incomparáveis para promover a reconciliação e a unidade solidária dos nossos povos" ${ }^{51}$ Essa "Igreja-sacramento de comunhão" se constrói e se renova a cada dia naquele mistério que está na raiz de sua própria origem e que é a fonte da sua existência: a liturgia. Como ação do próprio Cristo e da sua Igreja, a liturgia é "o exercício do sacerdócio de Jesus Cristo; é o ápice e a fonte da vida eclesial. É um encontro

${ }^{49}$ COMBLIN, J., Puebla, p. 201.

${ }^{50}$ DP 1294.

${ }^{51}$ DP 1302. 
com Deus, e os irmãos; banquete e sacrifício realizado na Eucaristia; festa de comunhão eclesial, na qual o Senhor Jesus; por seu mistério pascal". Nessa mesma linha de pensamento, "a liturgia é também força em nosso peregrinar, para que se leve a bom termo, mediante o compromisso transformador da vida, a realização plena do Reino, segundo o plano de Deus". ${ }^{52}$

Ao ser indagado sobre a importância da Conferência de Puebla para a Igreja na América Latina, J. B. Libânio declara ser Puebla um evento de enorme magnitude para a Igreja do nosso tempo. E a verdade dessa convicção se justifica, dentre outras coisas, por Puebla repropor ao nosso continente o modelo eclesiológico inaugurado pelo Concílio Vaticano II. ${ }^{53}$ A Igreja é, segundo o nosso Documento, "sacramento de Cristo", cujo carisma e missão é "comunicar aos homens a vida nova", a vida inaugurada pelo Senhor ressuscitado. ${ }^{54}$ Essa comunicação, em sua totalidade e plenitude, não seria jamais possível sem o mistério pascal continuamente celebrado, professado e testemunhado.

Movidos por essa convicção nos propusemos a dar um contributo a tantas indicativas que têmmobilizado a Igreja latino-americana na comemoração desse significativo jubileu do Documento de Puebla. E o nosso modesto contributo se justifica pela necessidade que temos de uma permanente formação, sempre em vista de um fomento da nossa participação na vida litúrgica da Igreja, conforme tanto anelou Puebla. ${ }^{55}$ Assim nos reconheceremos, cada vez mais, na nossa identidade de povo de Deus; um povo que, inserido num continente e numa história particulares, se torna capaz de unir-se a toda a Igreja, e, nela e com ela, numa estreita comunhão cósmica, com o mundo, por meio de Cristo, dinamizado pelo Espírito, para glória ao Pai!

\section{Referências bibliográficas}

COMBLIN, J. Puebla: vinte anos depois. Perspectiva Teológica, v.31, n.84, p. 201-222, mai./ago 1991.

BUYST, I. Sacramentalidade da liturgia na Sacrosanctum Concilium (SC). Constituição sobre a sagrada liturgia. In: CNBB. A Sagrada liturgia quarenta anos depois. São Paulo: Paulus, 2003. p. 88-102. (Doc. 87).

\footnotetext{
${ }^{52}$ DP 918. A liturgia é o exercício do sacerdócio de Cristo: SPERA, J. C.; RUSSO, R., Quem de nós celebra?, p. 121-122.

${ }^{53}$ LIBÂNIO, J. B., Nas pegadas de Medellín, as opções de Puebla.

${ }^{54}$ DP 922.

${ }^{55}$ DP 925.
} 
CASTELlAnO, J. Liturgia e vida espiritual. Teologia, celebração, experiência. São Paulo: Paulinas, 2008.

CATECISMO DA IGREJA CATÓliCA. Petrópolis: Vozes; São Paulo: Paulinas / Loyola / Ave-Maria, 1993.

CELAM. Documento de Puebla: texto conclusivo da III Conferência Geral do episcopado latino-americano. Petrópolis: Vozes, 1982.

CNBB. Liturgia: 20 anos de caminhada pós-conciliar. São Paulo: Paulinas, 1986. (Doc. 42)

CNBB. Por um novo impulso à vida litúrgica. São Paulo: Paulinas, 2008.

CONCÍLIO VATICANO II. Constituição Sacrossanctum Concilium sobre a sagrada liturgia. São Paulo: Paulinas. 2016.

CORBON, J. A fonte da liturgia. Lisboa: Paulinas, 1999.

ESCOBAR, F. A celebração do mistério de Cristo. In: CELAM (Org.). Manual de liturgia. A celebração do mistério pascal. Fundamentos teológicos e elementos constitutivos. São Paulo: Paulus, 2005. p. 13-75. v.2.

FRANCISCO, PP. Carta Encíclica Laudato Sì. Disponível em: https:/w2.vatican.va/content/dam/francesco/pdf/encyclicals/documents/ papa-francesco_20150524_enciclica-laudato-si_po.pdf $>$. Acesso em: 08 jun. 2019.

FRANCISCO, PP. Exortação Apostólica Evangelii Gaudium. São Paulo: Paulinas, 2013.

JAVIER FLORES, J. Introdução à teologia litúrgica. São Paulo: Paulinas, 2006.

JOÃO PAULO II, PP. Discurso do Papa João Paulo II na solene sessão de abertura da III conferência geral do episcopado latino-americano. $<\mathrm{http}$ :// w2.vatican.va/content/john-paul-ii/pt/speeches/1979/january/documents/hf_ jp-ii_spe_19790128_messico-puebla-episc-latam.html $>$. Acesso em: 01 jun. 2019.

KUNZLER, M. La liturgia della Chiesa. Milano: Jaca Book, 1996.

LAMBIASI, F. Lo Spirito Santo. Mistero e presenza. Bologna, Dehoniane, 1987.

LIBÂNIO, J. B. Nas pegadas de Medellín, as opções de Puebla. Disponível 
em: $<$ http://www.ihuonline.unisinos.br/index.php?option=com_content\&vie $\mathrm{w}=$ article $\& \mathrm{id}=1952 \&$ secao $=264>$. Acesso em: 01 jun. 2019.

LÓPEZ MARTÍN, J. A Liturgia da Igreja. São Paulo: Paulinas, 2006.

LUTZ, G. Uma leitura litúrgica global das Novas Diretrizes. In: CNBB. Liturgia na ação evangelizadora. Uma leitura litúrgica das Diretrizes Gerais da ação evangelizadora da Igreja do Brasil. Brasília: Edições CNBB, 2016. p. 7-13.

MALDONADO, L.; FERNANDÉZ, P. A celebração litúrgica. Fenomenologia e teologia da celebração. In: BOROBIO, D. (Org.). A Celebração na Igreja. São Paulo: Loyola, 1990. p. 161-282. v.1.

MARSILI, S. A liturgia, momento histórico da salvação. In: NEUNHEUSER, B. et al. A liturgia. Momento histórico da salvação. São Paulo: Paulinas, 1987. p. 39-190. v.1.

MARSILI, S. Sinais do mistério de Cristo. Teologia litúrgica dos sacramentos, espiritualidade e ano litúrgico. São Paulo: Paulinas, 2010.

MARSILI, S. Teologia Litúrgica. In: SARTORE, D.; TRIACCA, A. M. Dicionário de Liturgia. São Paulo: Paulinas/Paulistas, 1992. p. 1174-1187.

NEF ULLOA, B. A. Espiritualidade latino-americana a partir de Puebla. In: SOUZA, N.; SBARDELOTTI, E. (Orgs.). Puebla. Igreja na América Latina e no Caribe. Opção pelos pobres, libertação e existência. Petrópolis: Vozes, 2019. p. 110-120.

PALUDO, F. Vida litúrgica no Seminário. In: CELAM (Org.). Manual de liturgia. A celebração do mistério pascal. Introdução à celebração litúrgica. São Paulo: Paulus, 2004. p. 13-62. v.1.

PAULO VI, PP. Exortação Apostólica Evangelii Nuntiandi. São Paulo: Paulinas, 1976.

RAMOS, A. Evangelização e liturgia. In: SARTORE, D.; TRIACCA, A. M. Dicionário de Liturgia. São Paulo: Paulinas / Paulistas, 1992. p. 423-426.

ROSAS, G. O que celebramos? In: CELAM (Org.). Manual de liturgia. A celebração do mistério pascal. Introdução à celebração litúrgica. São Paulo: Paulus, 2004. p. 89-117. v.1.

SÁNCHEZ, V. Por que celebramos?. In: CELAM (Org.). Manual de liturgia. A celebração do mistério pascal. Introdução à celebração litúrgica. São Paulo: Paulus, 2004. p. 269-300. v.1. 
SANTOS FRADE, G. Puebla e a liturgia. In: SOUZA, N.; SBARDELOTTI, E. (Orgs.). Puebla. Igreja na América Latina e no Caribe. Opção pelos pobres, libertação e existência. Petrópolis: Vozes, 2019. p. 367-380.

SILVA, J. A. A celebração do mistério de Cristo ao longo da história. Panorâmica histórico geral da liturgia. In: CELAM (Org.). Manual de liturgia. A celebração do mistério pascal. Outras expressões celebrativas do mistério pascal e a liturgia na vida da Igreja. São Paulo: Paulus, 2007. p. 445518. v.4.

SODI, M. Liturgia: pienezza e momento della storia della salvezza. In: DELL'ORO, F. (Org.). Mysterion: nella celebrazione del mistero di Cristo la vita della Chiesa. Miscellanea liturgica in occasione dei 70 anni dell'abate Salvatore Marsili.Torino: Elle di Ci, 1981. p. 115-152.

SPERA, J. C.; RUSSO, R. Quem de nós celebra? In: CELAM (Org.). Manual de liturgia. A celebração do mistério pascal. Introdução à celebração litúrgica. São Paulo: Paulus, 2004. p. 119-150. v.1.

ZIZIOULAS, I. A criação como Eucaristia. Proposta teológica ao problema da ecologia. São Paulo: Mundo e Missão / Itesc, 2001.

\section{Luiz Fernando Ribeiro Santana}

Doutor em Teologia pela Pontifícia Universidade Católica do Rio de Janeiro Docente do Departamento de Teologia da Pontifícia Universidade Católica do Rio de Janeiro Rio de Janeiro / RJ - Brasil E-mail: 1.fernando2250@gmail.com

Recebido em: 05/07/19 Aprovado em: 10/08/19 